\title{
Guttenberg Case: International Perspectives
}

\author{
Svenja Falk, Abhinav Verma
}

\section{Key message}

This paper's intent is to provide a snapshot on perspectives in international media on the zu Guttenberg case in Germany. The review is based on an analysis of English speaking press from twelve countries. The paper uses the political communication triangle as the basic framework for analyzing the media perspectives. This triangle defines the three principal actors - political elites, media and civil society - as the independent building blocks of political communication.

\section{Context: Copygate - the international view}

The scandal around Karl-Theodor zu Guttenberg was a widely covered local event in the English speaking international press. Apart from Europe, the scandal was discussed at least once in leading newspapers in Australia, New Zealand, France, China, Canada, USA, UK and many others. This provides an opportunity to understand how the event was perceived in international media. Though the German public is familiar with the roles multiple actors played as the scandal emerged, it is interesting to understand the same from a third party perspective. Since this is an event of national significance, multiple actors including the government, opposition, media, NGOs, citizens, academia etc. played a critical role; they were referred to and commented on in press all across the globe.

\section{Framework: Political communication triangle}

Political communication research defines a triangle that refers to the principle actors involved in such communication. The triangle illustrates communication exchange among all the three principal actors - political elites, media and civil society. It reflects that any changes in one of the actors influences the other two(Römmele \& Gibson, 2008). Political elites include the government and the opposition parties, media entails all forms of communication channels, and society include academia, Internet activists and other parts of civil society.

Figure 1: Political Communication Triangle (Roemmele \& Gibson (2008))

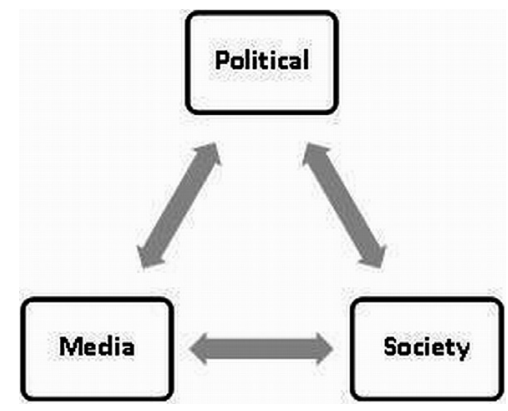

Selected international news articles have been studied over a three week period from February 17, 2011 to March 7, 2011. This horizon spreads from the time when plagiarism allegations first surfaced to one week post Guttenberg's resignation. The paper analyzes international commentary from the perspectives of the three principal actors (Figure 1) and explores their specific role in the scandal. Overall, international commentary focuses more on the role of media and society in the scandal, rather than on the political elites. There are three main topics that are discussed: the critical role of academia, specific cultural expectation by German society, and the influence of the media. These three topics provide important insights on the role of the principal actors throughout the scandal.

\subsection{Public intellectuals or the critical role of academia}

The news analysis published by the Economist indicates an interesting transition in the role of actors over time. While the view of political elites dominated the discussion in the beginning, society (i.e., the intellectual and the academic community) became the principal actors as times got difficult for the German ex-minister.

In the article "Heavy lifting", just a day after the plagiarism charges were reported, Guttenberg's charisma and his policies got maximum attention. ${ }^{1}$ Guttenberg's survival was dependent on the damage this affair would do to his credibility. On the day of resignation an article referred to the outrage from German's academic community that let him down. ${ }^{2}$ The focus still remained over Guttenberg's charisma, his rise in politics, support from Chancellor Merkel and the future of ruling CDU. Significant shift in a subsequent article "Guttbye Guttenberg" highlights the critical role of the academic community. The first few lines identify with this shift, "HIS boss backed him. The voters stood by him; it was the intellectuals who brought him down." It goes on to highlight the anger of academia over Mrs Merkel's remarks to differentiate between exemplary minister and corner-cutting doctoral candidate. ${ }^{3}$

This shift in the news analysis could be directly attributed to the critical role that academic community eventually played in Guttenberg's resignation: almost every news article published in the post resignation period highlights the pressure put by the academic community over Guttenberg and Merkel when she supported him. It is evident that the open letter from

1 The Economist. (2011). Heavy lifting? See http://www.economist.com/ blogs/newsbook/2011/o2/german_plagiarism_scandal. (last accessed March 23, 2012).

2 The Economist. (2011). Teflon no more. See http://www.economist.co $\mathrm{m} /$ node/21016431. (last accessed March 23, 2012).

3 The Economist. (2011). Guttbye Guttenberg. See http://www.economi st.com/node/18285902. (last accessed March 23, 2012). 
more than twenty thousand academics that came as a result of Merkel's support for Guttenberg increased pressure leading to his resignation. The academic perspective dominated that even the German minister of Education and Research Annette Schavan could not undermine the relevance of intellectual theft. ${ }^{4}$

\section{2 "Doctors in the House" Or dominant cultural expectation by German society}

The Economist attributes the entire episode to "strange love of doctorates" and compares the meager number of PhDs in American politics to the German lower house. The same article goes on to mention the weak relationship between doctoral education and politics through examples of politicians from other countries whose political careers survived post similar accusations. $^{5}$

In the International Herald Tribune which is the global edition of the New York Times, Dempsey highlights the role of expectations by the German society. ${ }^{6}$ She emphasizes the enormous respect German society has for those with academic titles. The opposition took this opportunity to puncture Guttenberg's popularity with the public.

Guttenplan in his article on the range of responses to plagiarism across cultures confirms the important role societal beliefs played in this case. ${ }^{7}$ Using the data point of more than 350 thousand responses to the Facebook page "We want Guttenberg back", he highlights the active participation of German citizens in such issues.

Apart from the US media, this cultural expectation has been focus of several articles published in the UK and Ireland. Oltermann's article in The Guardian uses the historical perspective to prove Germany's lead in matters of learning. ${ }^{8} \mathrm{He}$ mentions there is consensus that Germany was the first one to institutionalize academic research. The Irish Times is a perfect example where the issue of "Plagiarism" has been the central theme of articles on this scandal. The titles of 3 articles namely "Plagiarism allegations over German minister's thesis", "Plagiarism claims force minister from government" and "Plagiarism" are an indicator to the importance accorded to the seriousness around plagiarism. ${ }^{9}$ Even more, in the article "Plagiarism", the author expresses worry for Ireland academics where they see this as a cultural problem associated with the ease of cut-and-paste Internet use. Quality research has been directly related to a country's reputation. Concern over students' inability to understand wholesale lifting of material as intellectual theft is raised in the article. ${ }^{10}$

Similar to The Irish Times, New Zealand's Timaru Herald in its article "Can You Be A Plagiarist And Still A Leader?" creates a logical case of serious plagiarism with Guttenberg's thesis. The article compares the thesis to have lifted great clods from other lawns, whole flowerbeds from other gardens, and planted them in the final dissertation, without leaving a clue from where they came from. ${ }^{11}$ The above instances reflect the serious impact created by the scandal in the German political circles because of the dominant status provided to $\mathrm{PhDs}$ in the German society. The seriousness with which the plagiarism charges have been analyzed is a clear indicator of the dominant expectation.

\subsection{Being a hit with the press or Influence of the media}

The role of the German media has been emphasized in several international articles. The two different channels were highlighted in the discussion: the Internet as a medium to mobilize academia in this scandal, and the media participating in forming opinion that ultimately forced Guttenberg to resign. Though the former is an established fact, the latter has been referred to in several articles. Walker and McGroarty focus in the Wall Street Journal on Guttenberg's defense where he blames the two week frenzy by the media that made it impossible for him to continue. ${ }^{12}$ They also discuss the inquisition by the media and Internet activists even though the German voters supported Guttenberg and his continuation as Defence Minister through an opinion poll.

The French media has made constant reference to the role of the media in its articles. Agence France-Presse in its article "Schadenfreude at German 'cut-and-paste' minister" clearly identifies Guttenberg as a popular target for the German press. ${ }^{13}$ It mentions that the papers jumped on a series of minor scandals from alleged mutiny on a naval training ship to his handling of controversial Afghan airstrike. According to the news agency, the press has been responsible for turning his Afghanistan visit into a publicity stunt. The same article quotes a political analyst who expresses that the journalists find him arrogant. When Guttenberg resigned, a subsequent article attributed it to the increasing pressure from academics, media and even political allies. ${ }^{14}$ Similar article surfaced in

4 Dempsey, J. (2011). Setback for Merkel's party as rising star quits in plagiarism scandal. International Herald Tribune. See http://www.hi ghbeam.com/doc/1P1-190008105.html (last accessed March 23, 2012).

5 The Economist. (2011). Doctors in the House. See http://www.econo mist.com/node/18277131 (last accessed March 23, 2012).

6 Dempsey, J. (2011). Old thesis haunts a top minister; Letter from Europe. International Herald Tribune, Feb 22, 2011.

7 Guttenplan, D.D. (2011). A folly that can cost a reputation - or not; Range of responses to plagiarism reveals diversity across cultures. New York Times. See. http://www.nytimes.com/2011/03/07/educati on/o7iht-educLede.html?pagewanted=all. (last accessed March 23, 2012).

8 Oltermann, P. (2011). Karl-Theodor zu Guttenberg and his movable type. The Guardian. March 2, 2011.

9 Scally, D. (2011). Plagiarism claims force minister from government \& Scally, D. (2011). Plagiarism allegations over German minister's thesis. The Irish Times. March 3, 2011.

10 The Irish Times. (2011). Plagiarism. March 5, 2011.

11 Timaru Herald. (2011). CAN YOU BE A PLAGIARIST AND STILL A LEADER?

12 Walker, M. \& MCGroarty P. (2011). German Minister Quits Over Scandal; Fallout From Thesis Plagiarism Prompts Popular Defense Chief's Departure, in a Blow to Chancellor. The Wall Street Journal Online. March 2, 2011.

13 Sturdee, S. (2011). Schadenfreude at German 'cut-and-paste' minister. Agence France Presse. February 17, 2011.

14 Agence France Presse (2011). Germany's 'zu Googleberg' quits as MP too. 
The Australian that referred Guttenberg as never being a hit with the newspapers. ${ }^{15}$

Media's role cannot be restricted to pressure alone but also extends to the widespread ridicule in Germany over Guttenberg's name. "Name doctoring" as The Toronto Star calls it made sure that the newsworthiness of constant two week reporting remained intact. ${ }^{16}$ Names such as "Zu Copyberg" by ZDF television, "Baron Cut-and-Paste" by Financial Times Deutschland and "Zu Googleberg" by the daily Tageszeitung confirmed that media played a significant role in mounting pressure over Guttenberg till his resignation.

\section{Conclusion}

The topics revolving around the critical role of media and society in the Guttenberg case highlight how closely these actors in the political communication triangle influence each other. However, it is extremely difficult to evaluate the extent of influence they have on one another. As time passed post allegations, pressure increased over Guttenberg from media and society actors. He ultimately had to quit a post confirmed by voter support. What remains an unanswered question is whether the media and society influence political elites or they themselves act as political elites?

\section{Literature}

Römmele, A. \& Gibson, R. (2008). Political Communication. Comparative Politics. Oxford University Press.

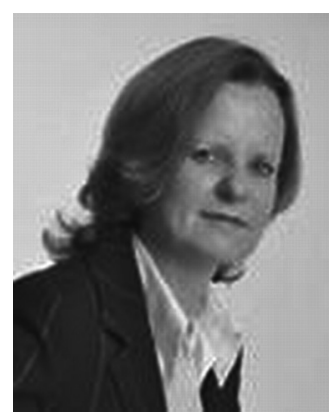

Dr. Svenja Falk works since 1999 at Accenture. She studied Political Sciences, Sociology and Philosophy at Justus-Liebig Universität Gießen and University of Southern California (Los Angeles). Academically, she is concerned with political consulting and media politics. Email: svenja.falk@accenture.com

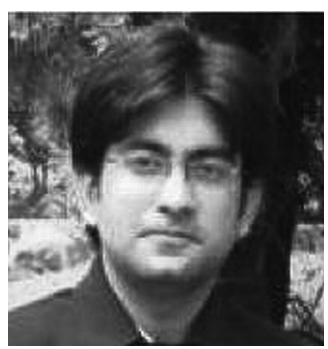

Abhinav Verma works with Accenture Management Consulting in Mumbai, India. He holds a masters degree in human resource management and labour relations from the Tata Institute of Social Sciences, Mumbai. His interest lies in the area of political communication and he has attended a training by the Hertie School of Governance, Berlin on the topic.
15 The Australian (2011). Thesis scandal fells Merkel superstar KarlTheodor zu Guttenberg. March 2, 2011.

16 The Toronto Star (2011). Name doctoring.

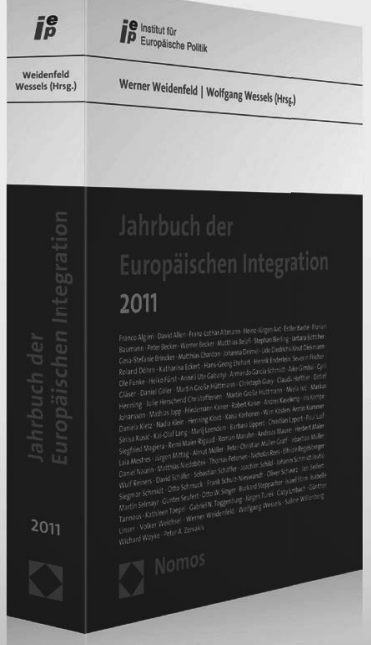

\section{Jahrbuch der Europäischen Integration 2011}

Herausgegeben von Werner Weidenfeld und Wolfgang Wessels

2012, 576 S., brosch., 49,- €, ISBN 978-3-8329-7211-0

Das Jahrbuch der Europäischen Integration des Instituts für Europäische Politik (Berlin) dokumentiert und bilanziert seit 1980 zeitnah und detailliert den europäischen Integrationsprozess. Themenschwerpunkte des Jahrbuchs 2011 bilden die mit der Wirtschafts- und Finanzkrise aufgeworfenen Fragen und das Ringen um europäische Antworten.

"In jedem Jahr eine wichtige Bestandsaufnahme."

Dr. Reinhard Scholzen, Europa - Unsere Zukunft 2009, zur Vorauflage 